\title{
Mode of p38 and Nf-kß Signalling Pathway on Induction of Apoptosis in Response to Flavonoids of Aloe Vera in Glioblastoma
}

\author{
Ashok Kumar ${ }^{1 *}$, Anupama Mahajan', Zarina Begum ${ }^{3}$ \\ ${ }^{1}$ Department of Biotechnology, Punjab Technical University, Jalandhar, Kapurthala. India \\ ${ }^{2,3}$ Department of Biotechnology, Saheed Udham Singh College of Engineering \& Technology, Mohali (PB), India \\ *Corresponding Author: ashoka.kumar2007@rediff.com Mob. : +91-94553-04726
}

Available online at: www.isroset.org

Received: 06/Feb/2019, Accepted: 23/Feb/2019, Online: 28/Feb/2019

\begin{abstract}
The phytochemical, Flavonoid has been shown apoptosis by numerous studies of cancer cell lines. Here, we have investigated the role of flavonoids of Aloe vera in regulation of apoptosis through $\mathrm{p} 38$ and $\mathrm{Nf}-\mathrm{k} \beta$ gene against human gliomaU87MG cells in vitro. The potential invasion of flavonoid on human glioma-U-87MG cells was examined by MTT assay and DNA fragmentation assay and expression of $\mathrm{p} 38$ and $\mathrm{Nf}-\mathrm{k} \beta$ gene was analysed by RT-PCR. Flavonoids significantly suppressed the apoptosis with $\mathrm{IC}_{50} 113.29 \pm 0.5 \mu \mathrm{g} / \mathrm{ml}$ and confirmed by DNA fragmentation assay. The results suggest that flavonoids induce apoptosis with decreased expression of p38 and $\mathrm{Nf}-\mathrm{k} \beta$ gene and protein analysis with SDS-PAGE. Assessments of cell viability represent that U-87MG cells were very sensitive to flavonoids and indicating DNA and protein synthesis delayed. In conclusion, flavonoids of Aloe showed inhibitory effect on Glioblastoma a brain tumor cells by apoptosis through regulation of p38 and $\mathrm{Nf}-\mathrm{k} \beta$ pathway at transcription and post -transcription level.
\end{abstract}

Keywords - Glioblastoma, Aloe vera, Flavonoids, p38, Nf-k $\beta$, U-87MG cell lines, RT-PCR, SDS-PAGE.

\section{INTRODUCTION}

Brain tumor (GBM-Glioblastoma) is one of most serious malignant tumor of central nervous system [1,2] and characterised by their aggressiveness, angiogenesis, deregulation of apoptosis, proliferation and difficult to treat with conventional therapies such as surgery, radiotherapy and chemotherapy. Patients suffering with GBM have survival rate of one year [3-7]. So, it's too difficult to treat GBM and therefore need to develop a novel therapy for prevent and treat Glioblastoma. Due to less issue, Plants and their extract's components could be alternative prevention for GBM. Aloe plant used as medicine in rural area and its flavonoids is used as drug for prevention of tumors because it can suppress brain tumor cells growth and progression and improved patient health from this lethal malignancy. Recently reported, that flavonoids isolated from Aloe, have antioxidant, anti-inflammatory and anticancer activity [8-10]. Flavonoids are polyphenolic natural compound introduced in a variety of fruits and vegetables. Aloe-emodin, aloesin, barbaloin, acemannan and anthreaquinone are major polyphenolic flavonoids, have been shown to inhibit the growth of brain, breast, ovary, lung and leukaemia cancer [11-13].
It has been revealed that flavonoids possessed cell differentiation modulation and inhibited phosphorylation of MAPK and activation of expression of $\mathrm{Nf}-\mathrm{k} \beta[1 \mathbf{1 0}, 14,16]$. Apoptosis is a natural process that's controlled by genetically in normal cell development and regulated by expression of many genes included Mitogens and their receptor, RAS/MAPK and Nuclear factor kappa B cells (Nf-kB) [1718], which also involved in tumorigenesis and induced biological activity as metabolism, metastasis, apoptosis, and cell proliferation and differentiation. Phosphorylation of $\mathrm{p} 38$ expressed oxidative stress, inflammatory cytokines included tumor necrosis factor (TNF- $\alpha$ ) and interleukin (IL-1 $1 \beta$ ). The phosphorylated MAPKs activation occurred by functional mutation in RAS and hyper-activation of p38 pathway concerned neoplastic transformation. Since, flavonoids functions as p38 expression inhibitor [19-21]. Afterward activation of p38 and $\mathrm{Nf}-\mathrm{kB}$, results in initiation of several gene including cyclooxygenase-2(COX-2), C-reactive protein (CRP), TNF- $\alpha$ and pro-inflammatory cytokines such as Interleukins (IL1, IL6) and employment of a major role in cancer [22-23]. The transcription factor $\mathrm{Nf}-\mathrm{k} \beta$ is become active on cytokine activation degradation of $\operatorname{Ik} \beta$ whereas $\mathrm{p} 38$ MAPK activation diverse in upstream kinases as well as downstream substrates. Both p38 MAPK and Nf-k $\beta$ are 
involved in regulation of transcriptional and posttranscriptional levels [24].

The major option for inhibit cancer morbidity and mortality is chemotherapy. Aggressive nature of GBM is due to high proliferation rate and resistance to chemotherapeutics drugs like temozolomide, cannabidiol, doxorubicin and carmustine etc. So, it is necessary to find new alternative treatment to amendment therapeutic effect against GBM with low side effect. Still, the growth inhibitory activity of flavonoids is to be studied on GBM and report described anti-neoplastic nature of flavonoids against U87MG cell line but had negligible effect over normal cells $[10,16]$. Anticancer activity of Aloe's flavonoids was correlated with decreased level of p38 and Nf-k $\beta$ expression in U87MG cells. Therefore, we suggest that flavonoids might be used in therapy of brain tumor. We observed that flavonoids decrease the viability of GBM cell. The low concentration $50 \mu \mathrm{M}$ of Aloe flavonoids expressed growth inhibition against U87MG cells. There are dozens of local plants and their constituents (also called secondary metabolites) as alkaloids, terpenoids, flavonoids, steroids, Saponins, polysaccharides; Glycosides, xanthone etc. may correlate with someone cellular signalling pathways. Flavonoids are specially isolated from leaves [16] and have been observed to increase apoptosis and inhibit invasion and metastasis by suppressing of p38 MAPK and Nf-k $\beta$ pathway with flavonoids. It does also have been found for association between above signalling pathway and flavonoids of Aloe. However, the present studies addressing the effect of flavonoids of Aloe on expression of $\mathrm{p} 38$ and $\mathrm{Nf}-\mathrm{k} \beta$ activation in GBM before and after treatment.

\section{MATERIAL AND METHOD}

\section{Drug Preparation}

Aloe vera was collected from Chandigarh region and all the chemicals used were analytical grade. Plant's leaves were cut in small pieces and dried under absence of light. After dried and grinding, 100gm of sample was placed in Soxhlet with solvent system (Methanol: Water) in $60 / 40$ ratio at $60^{\circ} \mathrm{C}$ for $24 \mathrm{hr}$ and crude extract obtained. The flavonoids are quantified with Aluminium chloride (spectrophotometric). In brief, $1 \mathrm{ml}$ of extract was added in methanolic aluminium chloride $(2 \%)$ and after $15 \mathrm{~min}$, determined the absorbance at $430 \mathrm{~nm}$. The crude extract was dried and make a solution with ethanol and poured into a column $(200 \times 5.0 \mathrm{~mm})$ packed with silica and again washed with $70 \%$ ethanol. The eluted flavonoids was collected and concentrated at $40^{\circ} \mathrm{C}$. High performance liquid chromatography (reversed phase, C18, 250mm x 416mm, Shimadzu) was used to identify the separated flavonoids according to their retention time (RT). The mobile phase consisted Toluene: Ethyl acetate: formic acid (7:5:1), injection volume was $20 \mu 1$, flow rate was $1.0 \mathrm{ml} / \mathrm{minutes}$ and wavelength was $350 \mathrm{~nm}$. Then purified flavonoids were kept at $-20^{\circ} \mathrm{C}$ for further study [25-26].

\section{Cell Line and Drug Treatment for Cell Cytotoxicity}

The human Glioblastoma (U87 MG - JOB CODE NCCS2007) cell lines were provided from NCCS (National centre for cell science), Pune, India and grown in Dulbecco's modified Eagle's medium (DMEM) with content supplement of $10 \%$ FBS (Fetal bovine serum) and $1 \%$ penicillinstreptomycin antibiotics in tissue culture flasks containing $5 \% \mathrm{CO}_{2}$ and $95 \%$ humidity at $37^{\circ} \mathrm{C}$. The cells were subcultured at 3-5 days interval for achieve cell count till $2 \mathrm{x}$ $10^{4}$. Then saline fraction of flavonoids was prepared in increasing concentration from 25, 50, 100, 200 and $400 \mu \mathrm{g} / \mathrm{ml}$. The drugs were treated in 96 well plate containing monolayer of U87MG cell lines. Negative control was U87MG cell line and Positive control was treated with Cisplatin $(20 \mathrm{mM})$. After incubation at $37^{\circ} \mathrm{C}$ for $24 \mathrm{hrs}$, remove spent media and after washing with Phosphate buffer (PBS), add MTT reagent $(0.5 \mathrm{mg} / \mathrm{ml})$ and again incubate for $3 \mathrm{hrs}$ and after solubilisation with saline, read the absorbance on ELISA reader at $570 \mathrm{~nm}$ with reference wavelength $630 \mathrm{~nm}$ in triplicate. The $\mathrm{IC}_{50}$ value calculated by linear regression equation $Y=M X \pm C$. where, $\mathrm{Y}=50, \mathrm{M}$ and $\mathrm{C}$ values were obtained from the viability graph.

\section{Apoptosis Analysis by Cell Viability}

With final $\mathrm{IC}_{50}$ concentration treated cells, cell growth and viability were measured by cells count using a haemocytometer. In brief, $0.5 \mathrm{ml}$ of the trypan blue solution $(0.4 \%)$ was transferred to a test tube, $0.3 \mathrm{ml}$ of PBS and 0.2 $\mathrm{ml}$ of the trypsinized cell suspension were added. The final solution was mixed and allowed to stand for $5 \mathrm{~min}$. Then load cell suspension onto both chambers of the haemocytometer. Cells were examined and counted in triplicates under light microscope at 40X10. Percentage cell viability was calculated by the formula: Cell viability $=$ No. of viable cells (unstained cells) $\times 100 /$ Total no. of cells (stained and unstained).

\section{DNA Fragmentation}

Before and after treatment, U87MG cells were centrifuged and washed with PBS and re-suspend the obtained pallets in DNA lysis buffer (200mM Tris, 100mM EDTA, 1\% SDS, $\mathrm{pH} 8.00)$ and $10 \mu \mathrm{l}(20 \mathrm{mg} / \mathrm{ml})$ proteinase $\mathrm{K}$ was added and incubate sample at $37^{\circ} \mathrm{C}$ for two hr and follow up extraction with phenol/chloroform and precipitate DNA sample in ethanol. After washing with $70 \%$ ethanol, DNA sample were re-suspended in TE buffer. Then Electrophoresis applied with $1 \%$ agarose gel with running buffer $(90 \mathrm{mM}$ Tris, $90 \mathrm{mM}$ Boric acid, $2 \mathrm{mM}$ EDTA, $0.5 \mu \mathrm{g} / \mathrm{ml}$ Ethidium bromide, $\mathrm{pH}$ 8.00) for $2 \mathrm{hr}$ at $10 \mathrm{~V} / \mathrm{cm}[\mathbf{2 7 - 2 8}]$.

\section{RNA Preparation and RT-PCR}

Reverse transcriptase polymerase chain reaction (RT-PCR) was performed to confirmed the over expression of p38 and $\mathrm{Nf}-\mathrm{k} \beta$ in U87MG cell line. Total RNA was isolated from before and after treatment, U87MG cells with Trizol reagent 
(INVITROGEN) in accordance to standardized protocol as such manufacturer suggested with small modification. Reverse transcription was performed on $5 \mu 1$ of total RNA using RT-PCR kit (Thermo-fisher) containing syber green in $25 \mu 1$ of reaction volume. This was carried out in triplicate and analysed using selected program Rotor-Gene Q Series Software version 2.3.1 (Build 49) QIAGEN. The primers were as follows-

\section{p38}

F-5'-TTGACTCAGATGCCGAAGATGAAC-3'

B-5'-TAGGCAAAGTAGGCATGTGCAAG-3'

Nf-k及

F-5'-ACCTGAGTCTTCTGGACCGCTG-3'

B-5'-CCAGCCTTCTCCCAAGAGTCGT-3'

At the end of reaction, the melting curve analysed for specificity of p38 and $\mathrm{Nf}-\mathrm{k} \beta$ expression.

\section{Protein isolation with cell lysis \& SDS-PAGE}

Before and after drug treatment, cells were lysed to isolate protein for SDS-PAGE performed. We used a modified method (). In brief, cells were harvested and lysed with lysis buffer $(50 \mathrm{mM}$ Tris, $150 \mathrm{mM} \mathrm{NaCl}, 20 \mathrm{mM}$ EDTA, $0.5 \%$ triton $\mathrm{X}-100,2.5 \mathrm{mM}$ sodium pyrophosphate, $1 \mathrm{mM} \beta$ glycerol-phosphate and $\mathrm{pH}$ - 7.50) and lysed cells were centrifuged at $15000 \mathrm{rpm}$ for $30 \mathrm{~min}$ at $4^{\circ} \mathrm{C}$ and collect the supernatants as protein and determined the concentration by Lowry method for performed SDS-PAGE. Total proteins $(20 \mu \mathrm{g} / \mathrm{ml})$ were separated with $10 \%$ SDS-PAGE electrophoresis.

\section{Statistical Analysis}

The parameters in this study were subjected to statistical analysis using Microsoft excel spread sheet. The results are expressed as mean \pm error of mean using Microsoft excel. For statistical assessment of the data, origin8 software was used. P-value of data was signified with $<0.05$.

\section{RESULT}

\section{Drugs}

The extraction of flavonoids observed in Aloe vera by extraction method and confirmed with high performance liquid chromatography. The level of total Phenolic content and flavonoids were 32.43 and 62.59 respectively.

Table 1 - Total phenolic content and Flavonoids of Aloe vera

\begin{tabular}{|c|c|c|c|c|c|}
\hline $\begin{array}{c}\text { Plant's } \\
\text { Name }\end{array}$ & $\begin{array}{c}\text { Plant's } \\
\text { part }\end{array}$ & Quantity & Extract & $\begin{array}{c}\text { Total } \\
\text { Phenolic } \\
\text { Content }\end{array}$ & Flavonoids \\
\hline & & $\mathrm{gm}$ & $\mathrm{Gm}$ & $\begin{array}{c}\mu \mathrm{g} \text { of } \\
\text { TAE/serving }\end{array}$ & $\mu \mathrm{g}$ of CE /serving \\
\hline $\begin{array}{c}\text { Aloe } \\
\text { vera }\end{array}$ & leaves & 100 & 5.44 & 16.97 & 21.84 \\
\hline
\end{tabular}

\section{Effect of flavonoids on GBM cell viability}

The effect of flavonoids was assessed by MTT assay on U87MG cell line, incubated for $24 \mathrm{hr}$ with different doses of flavonoids $(25,50,100,200,400 \mu \mathrm{g} / \mathrm{ml})$ in compare to $20 \mathrm{mM}$ Cisplatin. It's performed to study mitochondrial/ nonmitochondrial dehydrogenase activity for flavonoids as cell cytotoxicity. The result revealed that $\mathrm{IC}_{50}$ value for flavonoids of Aloe was $113.29 \pm 0.5 \mu \mathrm{g} / \mathrm{ml}$ against U87MG cell lines and was toxic in nature for GBM. At initial concentration of flavonoids of $25 \mu \mathrm{g} / \mathrm{ml}$, U87MG cell viability decreased consistently from 70.49 to $19.95 \%$ at concentration of $400 \mu \mathrm{g} / \mathrm{ml}(\mathrm{P}<0.05)$.

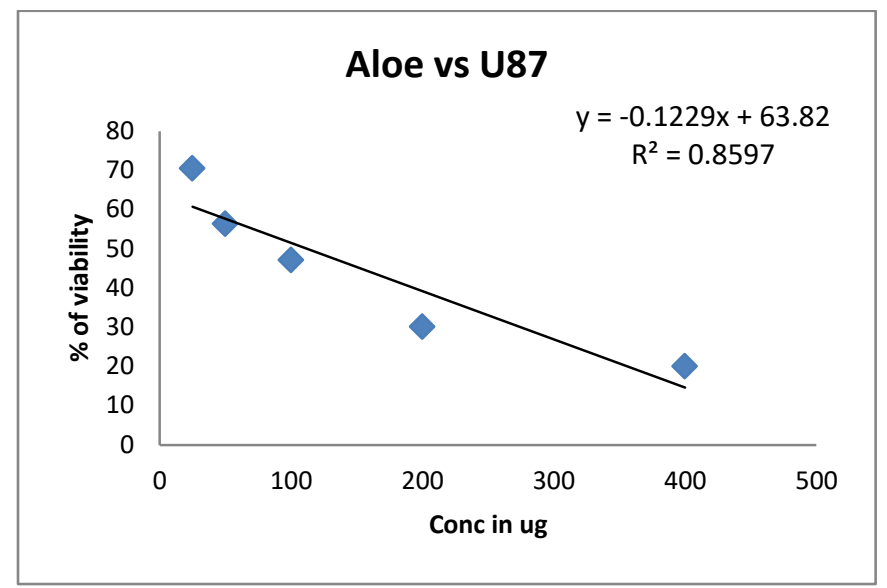

Figure 1- Flavonoids decrease the viability of Glioblastoma (U87MG) cell lines

\section{Effect of flavonoids on GBM cell proliferation and apoptosis}

Morphology of cell lines were examined in microscope and observed that cells are shrinkage, with increasing of concentration of flavonoids, percentage of dead cell increased and detects high percentage of apoptosis. We ensure that growth inhibitory effect was due to cellular apoptosis. MTT assay revealed that apoptosis in Glioblastoma is a concentration dependent. In untreated cells, apoptosis was negligible but when it was treated with $25 \mu \mathrm{g} / \mathrm{ml}$ flavonoids then, it's also observed that $\mathrm{IC}_{50}$ of flavonoids were highly significant. There was also morphogical changes observed that associated with apoptosis like membrane blobbing, nuclear condensation, DNA fragmentation in treated cells. Aloe's flavonoids represented dose dependent effect. So, our data suggest that flavonoids should be selective towards brain tumor than normal. 


\title{
ALOE VERA 1
}

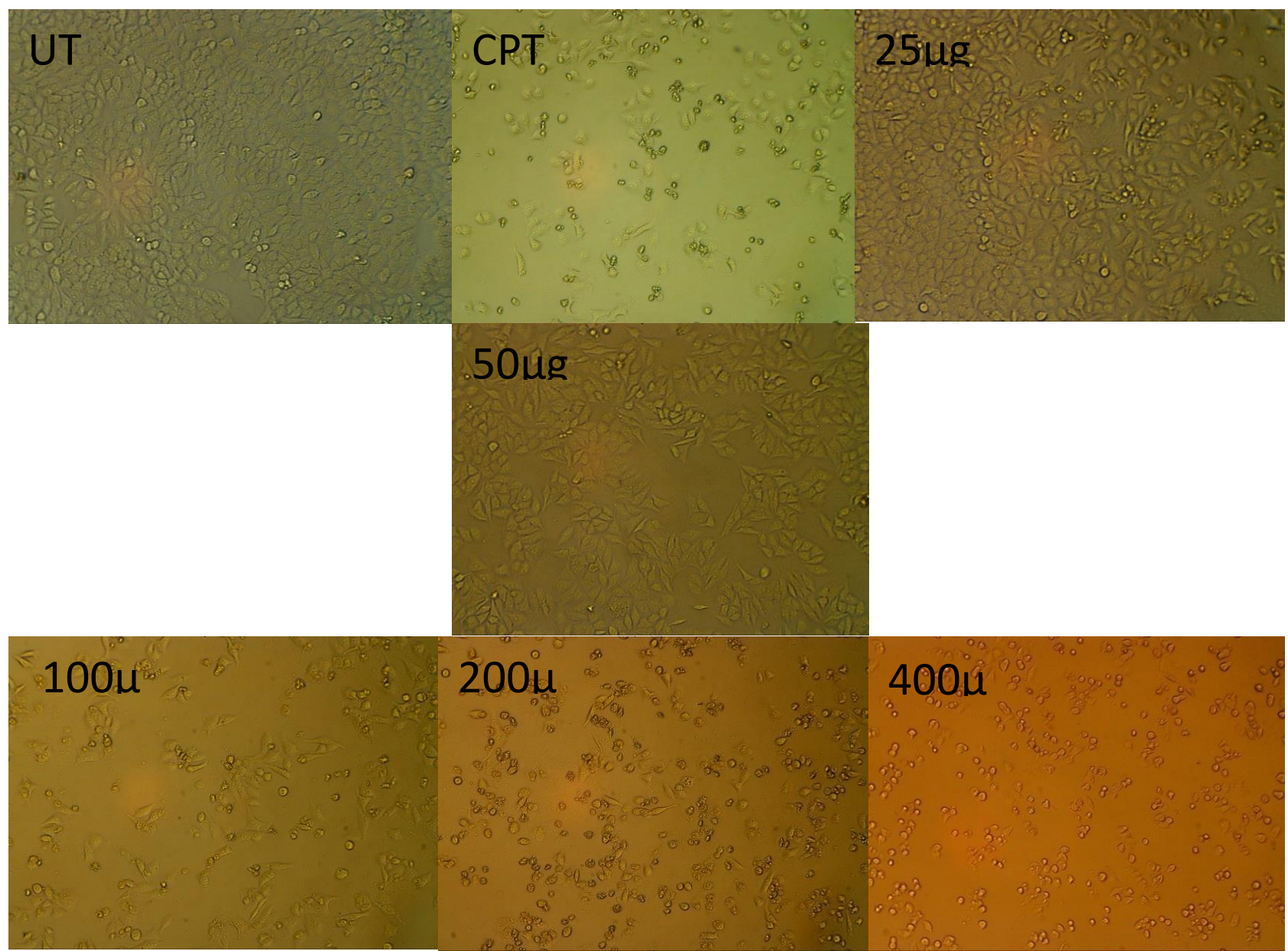

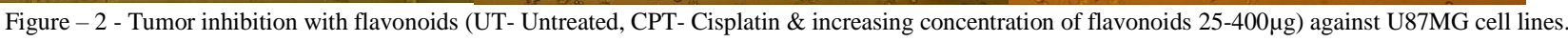

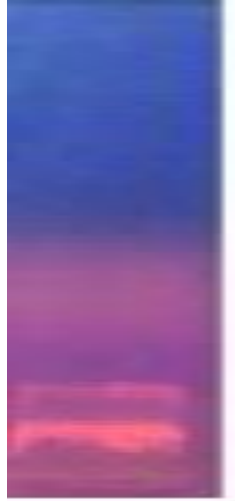

L17
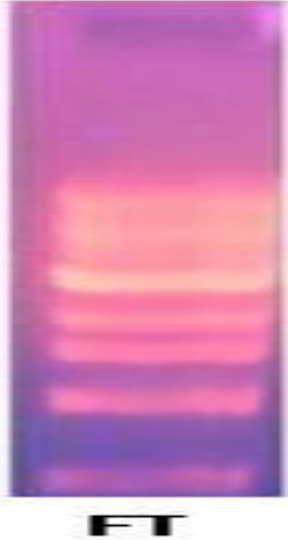

Figure - 3-DNA Fragmentation of Untreated and flavonoids treated against DNA marker

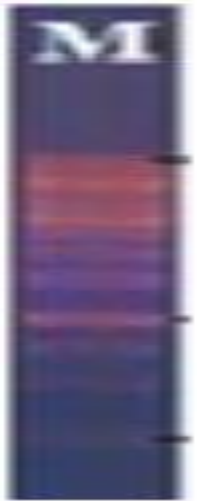

Thro

\begin{abstract}
Signalling Pathways involved the growth inhibition activity of flavonoids

$\mathrm{p} 38$ and $\mathrm{Nf}-\mathrm{k} \beta$ genes are main factor for regulation of apoptosis and expressed against housekeeping $\beta$-Actin gene and normalized in normal cells. As Real Time PCR evaluation of flavonoids $(139.02 \pm 0.5 \mu \mathrm{g} / \mathrm{ml})$ treated U87MG cell lines showed a significant dose and time dependent decreased expression of $\mathrm{p} 38$ and Nf-kB. As evident from result, now clear that p38 play a key role in modulation of apoptosis. The activation of MAPK and Nf-k $\beta$ decreased expression from normal expression with significant dose of flavonoids in GBM. These results suggest that flavonoids induce apoptosis with activation of caspase -3 through increased ratio of $\mathrm{Bax} / \mathrm{Bcl}-\mathrm{xL}$ by decreased expression of p38.
\end{abstract}




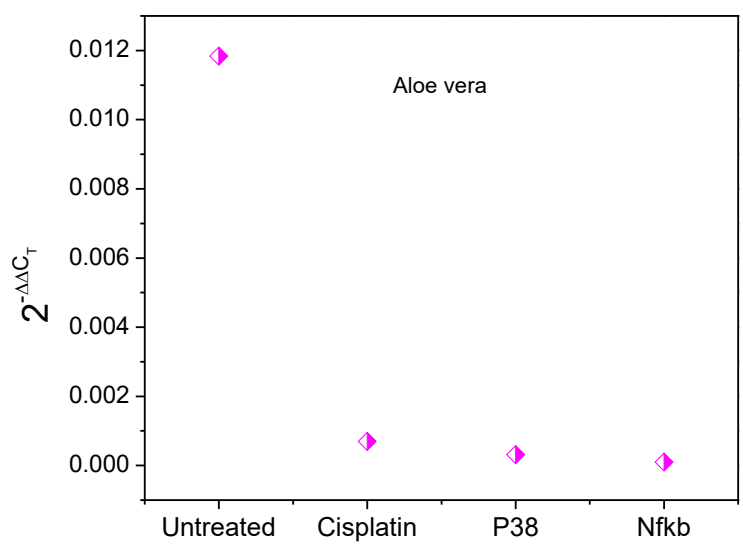

Figure 4 - Real time PCR analysis of p38 and Nf-kB gene in U87MG cell lines show the suppression of gene expression in treated cells with flavonoids and Cisplatin compared to Untreated.

\section{Analysis of Expression of $\mathrm{p38}$ and $\mathrm{Nf}-\mathrm{k} \boldsymbol{\beta}$ proteins}

As shown in figures SDS-PAGE, protein expression of $\mathrm{p} 38$ and Nf-k $\beta$ in untreated and treated U87MG cell lines. When compared the result with control then confirmed the results from RT-PCR. Flavonoids treated cells death was investigated by monitoring of apoptotic proteins of U87MG cell lines with decreased expression of proteins at SDS PAGE. As shown in fig, exposure of flavonoids decreased concentration of protein after $24 \mathrm{hr}$ treatment. Further results revealed that flavonoids induced Caspase 7 and promote morphological changes of apoptotic cells. In apoptotic cells, figure showed that flavonoids induced cell's proteins appear as degraded. [29-30]. The above results indicate that plant pigments induced cell deaths in U87MG by apoptosis with modulation of signalling pathway.
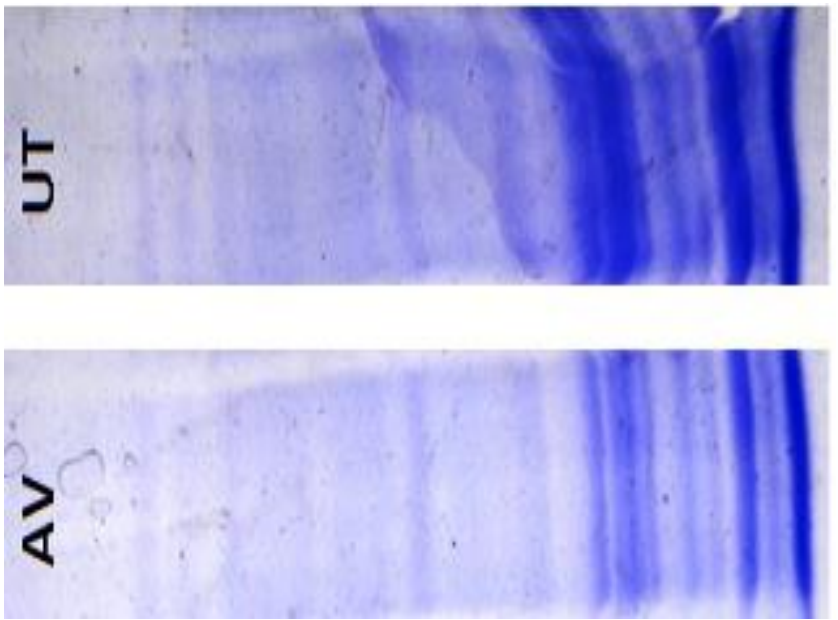

Figure - 5- Protein analysis expressed the decreased the protein level in flavonoids treated U87mg cell lines.

\section{DISCUSSION}

The Phenolic compounds are most ubiquitous plants metabolites. Flavonoids are hydroxylated known phenolic substances synthesized by plant. Aloe could be regarded as medicine due to flavonoids content in them. Flavonoids play an important and varied role as secondary metabolites. There are of particular importance in the human diet as there is evidence that they act as free radical scavengers, antioxidants, and diuretic, antiviral, antibacterial, antimicrobial, anti-inflammatory, anti-tumor, anti-platelets agents $[\mathbf{8}, 31]$. Here, many chemotherapeutics drugs were cytotoxic against normal cells. Therefore, it's considerable for cure cancer and should be valuable alternative source [32-33]. Number of in vitro studies represents the treatment and prevention of brain tumor (Glioblastoma) carried by flavonoids and affects the initiation, promotion, metastasis and proliferation of GBM [34].

In present study, we have analysed the effect of flavonoids at U87MG cell lines. These antioxidant flavonoids assessed invitro growth and anti-proliferation of U87MG cells using cytotoxicity assay. It's expressed the reduction of cell viability as others have reported [31, 35-37]. Our results indicate, DNA fragmentation increased with apoptosis increased as compared to control [38]. To define the role of flavonoids in brain tumor invasion and metastasis, we used U87MG cell line because this is highly invasive and metastatic in nature. U87 cells are responsive to flavonoids for suppressive effect of growth and increased apoptosis. As shown in figure, expression of $\mathrm{p} 38$ and $\mathrm{Nf}-\mathrm{k} \beta$ exhibit less in treated as compared to untreated. Although there is not yet precise mechanism for understood regulate the GBM invasion and metastasis. It has been suggested that many signalling pathway including $\mathrm{p} 38$ and $\mathrm{Nf}-\mathrm{k} \beta$ to promote the invasion of brain tumors. The most important constituents of Aloe vera are aloin, barbaloin, anthranol, cinnamic acid, aloetic acid, emodin, chrysophanic acid, resistanol, and enzymes. Some of them are flavonoids, can affect the initiation, promotion as well as progress stage of brain tumors $[34,38]$.

Some studies revealed that flavonoids of Aloe have mutagenic and genotoxic effects and that were confirmed with DNA fragmentation assay and RT-PCR. Aloe-emodin, one of flavonoids has anticancer and cytotoxic activity against brain tumor, lung cancer and liver cancer. In our study, we have found that cytotoxicity of Aloe's flavonoids could be through modulation of apoptosis against brain tumors (U87MG) cells. Both gene and protein expression for $\mathrm{p} 38$ and $\mathrm{Nf}-\mathrm{k} \beta$ were significantly different in without and with treatment. In our studies, we found that flavonoids induced $\mathrm{p} 38$ and $\mathrm{Nf}-\mathrm{k} \beta$ gene expression significantly reduced and these observations showed that $\mathrm{p} 38$ and $\mathrm{Nf}-\mathrm{k} \beta$ gene expression suppressed with flavonoids and regulate 
transcription gene. $\mathrm{p} 38$ and $\mathrm{Nf}-\mathrm{k} \beta$ are major pathway groups for regulation of cell death programming included morphological changes, DNA damage, and gene and protein expressions through induction of apoptotic pathway.

Previous studies revealed to lead to reduce the cell proliferation with cell cycle arrest at many stages. Cell cycle is an important regulatory phenomenon to regulate cell growth and differentiation with cascade's enzyme and activation-inactivation of cyclin and cyclin-dependent kinases (CDKs). Cell cycle arrest and apoptosis can be initiated by flavonoids of Aloe. It does also enhance the expression of p21 and p27 to block cell cycle at G1 phase and led to apoptosis in cancer. It's also found that flavonoids were effective in prevention of neuronal apoptosis via phosphorylation of p38 signalling pathway and $\mathrm{Nf}-\mathrm{k} \beta$ regulation $[14,23]$.

p38 signalling pathway is a regulators to lead oncogenes expression. There is evidenced that $\mathrm{p} 38$ participate in cox-2 gene expression by hypertonic solution and lipopolysaccharides and p38's inhibitor stopped cox-2 mRNA. Nf-k $\beta$ activation can be regulated by multiple mechanisms and cross references represents that $\mathrm{Nf}-\mathrm{k} \beta$ activation is regulated by p38 [39]. It's also reported that $\mathrm{Nf}-\mathrm{k} \beta$ and its associated cytokines initiate inflammation and cancer causing factors and is activated by degradation of $\operatorname{Ik} \beta$ to lead physiological response. Nf-k $\beta$ is a transcription factor, responsible for gene involved in growth, cell survival, inflammation and differentiation. Flavonoids reduced p38 and Nf-k $\beta$ expression that modulated by $\mathrm{p} 38$ MAPKs. With inhibition of p38 pathway significantly reduced the expression of Nf-k $\beta$ due to low binding of TBP to TATA box [40-41].

Previous studies [42-43] expressed that flavonoids compound inhibited angiogenesis in cancer. VEGF is key regulator in tumor development, maintenance and promotes angiogenesis by stimulating tumor growth and metastasis [44]. Recent studies showed that flavonoids inhibited angiogenesis, indicated the inhibition potential in tumor growth [35]. Some researcher showed that expression, activation and translocation of $\mathrm{Nf}-\mathrm{k} \beta$ is regulated by Akt pathway and suppression of $\mathrm{Nf}-\mathrm{k} \beta$ expression with flavonoids in U87MG cells, indicated the role of Nf-k $\beta$ and Akt pathway in cell proliferation and apoptosis [36]. Our conducted work agree with in vitro studies, that flavonoids reduced number of cells with increasing concentration, growth rate, reduced viability of cells [37]. On sum-up, previous studies and our results represent the potential of flavonoids to find and development of new drugs. The challenge of chemotherapy in tumor is that chemotherapeutic drugs are toxic for normal cells. So, flavonoids will be alternative in Glioblastoma treatment.

\section{CONCLUSION}

In present investigation, we observed the role of flavonoids in regulation of brain tumor invasion. Flavonoids of Aloe could have cytotoxic and genotoxic activity against GBM. Aloe constituents showed morphological changes, DNA damage, gene and protein associated apoptosis of GBM. Based on above works, we concluded that p38 and Nf-k $\beta$ activation are significantly inhibited by $139 \mu \mathrm{g} / \mathrm{ml}$ flavonoids and this dose is achievable. Our results demonstrated that flavonoids play an inhibitory role in brain tumor invasion by decrease the expression of $\mathrm{p} 38$ and $\mathrm{Nf}-\mathrm{k} \beta$ signalling pathway through induction of apoptosis. So, flavonoids regulate the growth of tumor, angiogenesis, apoptosis and modulation of cell regulatory pathway as $\mathrm{p} 38$ and $\mathrm{Nf}-\mathrm{k} \beta$ signalling pathway. Therefore, it should be considered a potential anticancer agent and continue more research both in-vitro and in-vivo.

\section{Conflict of Interest}

None

\section{Acknowledgement}

The Authors Would like to acknowledge the department of Biotechnology, Saheed Udham Singh College of Engineering \& Technology (SUSCET), Mohali and Centre of Microbiology \& Biotechnology (CMBT), Bhopal for provide the research facility and fair working environment.

\section{REFERENCES}

[1]. De Angelis LM “Brain tumors" N Engl J Med 344:114-123, 2001. doi:10.1056/NEJM200101113440207

[2]. Louis DN, Ohgaki H, Wiestler OD, Cavenee WK, Burger PC, "The 2007 WHO classification of tumours of the central nervous system." Acta Neuropathol 114: 97-109, 2007.

[3]. Wen PY, Kesari S "Malignant gliomas in adults." N Engl J Med 359: 492- 507, 2008.

[4]. Wei J, Gabrusiewicz K, Heimberger A "The controversial role of microglia in malignant gliomas" Clinical \& developmental immunology", 285-246, 2013.

[5]. Stupp R, Mason WP, van den Bent MJ, Weller M, Fisher B, "Radiotherapy plus concomitant and adjuvant temozolomide for glioblastoma" The New England journal of medicine 352: 987996, 2005.

[6]. Stupp R, Hegi ME, Mason WP, van den Bent MJ, Taphoorn MJ, "Effects of radiotherapy with concomitant and adjuvant temozolomide versus radiotherapy alone on survival in glioblastoma in a randomised phase III study: 5-year analysis of the EORTC-NCIC trial". The lancet oncology 10: 459-466, 2009.

[7]. Rock K, McArdle O, Forde P, Dunne M, Fitzpatrick D, "A clinical review of treatment outcomes in glioblastoma multiforme-the validation in a non-trial population of the results of a randomised Phase III clinical trial: has a more radical approach improved survival?" The British journal of radiology 85: e729-733, 2012.

[8]. Yagi A, Kabash A, Okamura N, Haraguchi H, Moustafa SM, Khalifa TI. "Antioxidant, free radical scavenging and antiinflammatory effects of aloes in derivatives in Aloe vera" Planta Med, 68(11):957-60, 2002.

[9]. Pugh N, Ross SA, ElSohly MA, Pasco DS. "Characterization of Aloeride, a new high-molecular-weight polysaccharide from Aloe 
vera with potent immunostimulatory activity" J Agric Food Chem 49(2):1030-4, 2001.

[10]. Fishman DA and Schwartz PE: "Current approaches to diagnosis and treatment of ovarian germ cell malignancies". Curr Opin Obstet Gynecol 6: 98-104, 1994.

[11]. Pecere T, Gazzola MV, Mucignat C, Parolin C, Vecchia FD, Cavaggioni A. "Aloe-emodin is a new type of anticancer agent with selective activity against neuroectodermal tumors" Cancer Res 60: 2800-4, 2000.

[12]. Rodrigueg J, Yanez J, Vicente V, Alcaraz M, Benavente-García O, Lazona JA, "Effects of several flavonoids on the growth of B16f10 and SKMEL- 1 melanoma cell lines: Relationship between structure and activity" Melanoma Res 12:99-107, 2002.

[13]. Yonehara A, Tanaka Y, Kulkeaw K, Era T, Nakanishi Y, Sugiyama D. "Aloe vera Extract Suppresses Proliferation of Neuroblastoma Cells In Vitro" Anticancer Res 35(8):4479-85, 2015.

[14]. Xiao, B. X.; Guo, J. M.; Liu, D.H.; Zhang, S. "Aloe-emodin induces in vitro $G 2 / M$ arrest and alkaline phosphatase activation in human oral cancer KB cells" Oral Oncol., 43, 905. 2007,

[15]. Fishman DA and Schwartz PE: "Current approaches to diagnosis and treatment of ovarian germ cell malignancies" Curr Opin Obstet Gynecol 6: 98-104, 1994.

[16]. Birt DF, Hendrich S and Wang W, "Dietary agents in cancer prevention: Flavonoids and isoflavonoids" Pharmacol Ther 90:157-177, 2001.

[17]. Lee FS, Hagler J, Chen ZJ, Maniatis T "Activation of the IkappaB alpha kinase complex by MEKK1, a kinase of the JNK pathway" Cell, 88:213-22, 1997.

[18]. Schwenger P, Alpert D, Skolnik EY, Vilcek J, “Activation of p38 mitogen-activated protein kinase by sodium salicylate leads to inhibition of tumor necrosis factor-induced IkBa phosphorylation and degradation" Mol Cell Biol; 18:78-84, 1998.

[19]. Beyaert R, Cuenda A, Vanden Berghe W, Plaisance S, Lee JC, Haegeman G, "The p38/ERK mitogen-activated protein kinase pathway regulates interleukin-6 synthesis response to tumor necrosis factor" EMBO J; 15:1914-23, 1996.

[20]. Vanden Berghe W, Plaisance S, Boone E, De Bosscher K, Schmitz ML, Fiers W. "p38 and extracellular signal-regulated kinase mitogen-activated protein kinase pathways are required for nuclear factor-kappa B p65 transactivation mediated by tumor necrosis factor" J Biol Chem; 273:3285-90, 1998.

[21]. Wang D, Baldwin AJ, "Activation of nuclear factor-kappa Bdependent transcription by tumor necrosis factor-alpha is mediated through phosphorylation of RelA/p65 on serine 529" J Biol Chem; 273:29411-6, 1998.

[22]. Naldini, A.; Carraro, F, "Role of inflammatory mediators in angiogenesis" Curr. Drug Targets Inflamm. Allergy, 4, 3-8, 2005.

[23]. Goldberg, J.E.; Schwertfeger, K.L. "Proinflammatory cytokines in breast cancer: Mechanisms of action and potential targets for therapeutics" Curr. Drug Targets, 11, 1133-1146, 2010.

[24]. Carter AB, Knudtson KL, Monick MM, Hunninghake GW, "The p38 Mitogen-activated Protein Kinase Is Required for NF- $\kappa B$ dependent Gene Expression” J Biol Chem ; 274:30858-63, 1999.

[25]. G. R. Waller, S. Mangiafico $\dagger$ and C. R. Ritchey "A Chemical Investigation of Aloe Barbadensis Miller” Proc. Okla. Acad. Sci. 58: 69-76, 1978.

[26]. Miyuki Tanaka, Eriko Misawa, Yousuke Ito, Noriko Habara, Kouji Nomaguchi, Muneo Yamada, Tomohiro Toida, Hirotoshi Hayasawa, Mitunori Takase, Masanori Inagaki, And Ryuuichi Higuchi "Identification of Five Phytosterols from Aloe Vera Gel as Anti-diabetic Compounds" Biol. Pharm. Bull. 29(7) 14181422, 2006.

[27]. Hsu, S. L.; Yin, S. C.; Liu, M. C.; Reichert, U.; Ho, W. L. "Involvement of cyclin-dependent kinase activities in CD437induced apoptosis" Exp. Cell Res., 252, 332, 1999.
[28]. Sambrook, J., Fritsch, E.F., and Maniatis, T. "Molecular Cloning. A Laboratory manual" Cold Spring Harbor Laboratory Press, Cold Spring Harbor, NY, 1989.

[29]. Araya R, Takahashi R, Nomura Y, "Yeast two-hybrid screening using constitutive-active caspase-7 as bait in the identification of PA28gamma as an effector caspase substrate" Cell Death Differ, 9:322-8, 2002.

[30]. Xie J, Guo Q, Zhu H, Wooten M, Mattson M, "Protein kinase Ciota protects neural cells against apoptosis induced by amyloid beta-peptide" Mol Brain Res, 82:107-13, 2000.

[31]. Reynolds, T.; Dweck, A.C, "Aloe vera leaf gel: a review update" J. Ethnopharmacol., 68, 3, 1999.

[32]. Chidambaram, M.; Manavalan, R.; Kathiresan, K. "Nanotherapeutics to overcome conventional cancer chemotherapy limitations" J. Pharm. Pharm. Sci. 14, 67-77, 2011.

[33]. Bosetti C, Rossi M, McLaughlin JK, Negri E, Talamini R, Lagiou P, Montella M, Ramazzotti V, Franceschi S and LaVecchia C: "Flavonoids and the risk of renal cell carcinoma" Cancer Epidemiol Biomarkers Prev 16: 98-101, 2007.

[34]. Mijatovic, S.; Maksimovic-Ivanic, D.; Radovic, J.; Popadic, D.; Momcilovic, M.; Harhaji, L.; Miljkovic, D.; Trajkovic, V, "Aloe emodin prevents cytokine-induced tumor cell death: the inhibition of auto-toxic nitric oxide release as a potential mechanism" Cell Mol. Life Sci., 61, 1805, 2004.

[35]. Lam KH, Alex D, Lam IK, Tsui SK, Yang ZF and Lee SM, "Nobiletin, a polymethoxylated flavonoid from citrus, shows antiangiogenic activity in a zebrafish in vivo model and HUVEC in vitro model" J Cell Biochem 112: 3313-3321, 2011.

[36]. Van Uden P, Kenneth NS and Rocha S, "Regulation of hypoxiainducible factor-1 $\alpha$ by NF-kappa B" Biochem J 412: 477484, 2008.

[37]. Arafa SA, Zhu Q, Barakat BM, Wani G, Zhao Q, El-Mahdy MA and Wani AA, "Tangeretin sensitizes cisplatin-resistant human ovarian cancer cells through down-regulation of phosphoinositide 3-kinase/Akt signaling pathway" Cancer Res 69: 8910-8917, 2009.

[38]. Lee, H-Z; Lin, C-J; Yang, W-H; Leung, W-C; Chang, S-P, "Aloeemodin induced DNA damage through generation of reactive oxygen species in human lung carcinoma cells" Cancer Lett., 239, $55,2006$.

[39]. Lee FS, Hagler J, Chen ZJ, Maniatis T, "Activation of the IkappaB alpha kinase complex by MEKK1, a kinase of the JNK pathway" Cell , 88:213-22, 1997.

[40]. Carter AB, Knudtson KL, Monick MM, Hunninghake GW, "The p38 mitogen-activated protein kinase is required for NF-kappa Bdependent gene expression. The role of TATA-binding protein (TBP) "' J Biol Chem, 274:30858-63, 1999.

[41]. K.-S. Chun, Y.-J. Surh, "Signal transduction pathways regulating cyclooxygenase-2 expression: potential molecular targets for chemoprevention" Biochemical Pharmacology 68, 1089-1100, 2004.

[42]. Lam IK, Alex D, Wang YH, Liu P, Liu AL, Du GH and Lee SM, "In vitro and in vivo structure and activity relationship analysis of polymethoxylated flavonoids: Identifying sinensetin as a novel antiangiogenesis agent" Mol Nutr Food Res 56: 945-956, 2012.

[43]. Luo H, Rankin GO, Liu L, Daddysman MK, Jiang BH and Chen YC, "Kaempferol inhibits angiogenesis and VEGF expression through both HIF dependent and independent pathways in human ovarian cancer cells" Nutr Cancer 61: 554-563, 2009.

[44]. Forsythe JA, Jiang BH, Iyer NV, Agani F, Leung SW, Koos RD and Semenza GL, "Activation of vascular endothelial growth factor gene transcription by hypoxia-inducible factor 1" Mol Cell Biol 16: 4604-4613, 1996 